\title{
Gaya Hidup dan Kreativitas (Studi Deskriptif Kualitatif pada Anton Ismael)
}

\author{
Calvin, Gregorius Genep Sukendro \\ calvin.915150118@stu.untar.ac.id,geneps@fikom.untar.ac.id
}

Fakultas Ilmu Komunikasi Universitas Tarumanagara

\begin{abstract}
A person's lifestyle has a huge impact on the individual. Creativity is a mindset that is very loaded with tactics. Creative lifestyle is a pattern of behavior in which the individual conducts daily activities with creative things so that the individual becomes a creative human being. Anton Ismael is a creative person who works as a photographer, as a human being Anton Ismael also has a lifestyle that he does every day. This research was conducted to discuss Anton Ismael's Lifestyle so as to make him a creative human in his field, namely a photographer. The approach used in this research is descriptive qualitative, with the type of case study. The subject of this study was Anton Ismael, while the objects in this study were Lifestyle and Creativity. Data collected by conducting interviews, observation, and literature study. The conclusion of this study is that Anton Ismael's Lifestyle helped the formation and development of his creative process as a photographer. Anton Ismael's lifestyle is like making friends with everyone, always developing networks, continuing to learn, self-elaboration, these are the things that really encourage Anton Ismael's creative ability to make him a creative man like now.
\end{abstract}

Keywords: Lifestyle, Creativity, Anton Ismael

\begin{abstract}
Abstrak
Gaya hidup seseorang memiliki dampak yang sangat besar bagi individu itu sendiri. Kreativitas merupakan sebuah pola pikir yang sangat sarat akan sebuah siasat. Gaya hidup kreatif merupakan sebuah pola perilaku seseorang dimana individu tersebut melakukan kegiatan sehari-harinya dengan hal-hal yang kreatif sehingga menjadikan individu tersebut sebagai manusia kreatif. Anton Ismael merupakan orang kreatif yang berprofesi sebagai fotografer. Anton Ismael memiliki gaya hidup yang dilakukannya setiap hari. Penelitian ini dilakukan untuk membahas gaya hidup Anton Ismael sehingga menjadikan dia manusia kreatif pada bidangnya yaitu fotografer. Pendekatan yang digunakan dalam penelitian ini adalah kualitatif deskriptif, dengan jenis studi kasus. Subjek penelitian ini adalah Anton Ismael, sedangkan objek pada penelitian ini adalah gaya hidup dan kreativitas. Data yang dikumpulkan dengan melakukan wawancara, observasi, dan studi kepustakaan. Kesimpulan dari penelitian ini adalah gaya hidup Anton Ismael membantu pembentukan dan pengembangan proses kreativitas dirinya yang berprofesi sebagai fotografer. Gaya hidup Anton Ismael seperti berteman dengan semua orang, selalu mengembangkan jaringan, terus belajar, elaborasi diri, itulah hal-hal yang sangat mendorong kemampuan kreativitas Anton Ismael sehingga menjadikan dia manusia kreatif seperti sekarang.
\end{abstract}

Kata Kunci: Gaya Hidup, Kreativitas, Anton Ismael 


\section{Pendahuluan}

Era modern seperti sekarang mendorong manusia untuk bersaing dengan kehidupan agar tetap hidup. Salah satu yang memudahkan manusia untuk bersaing adalah dengan menjadi kreatif dan meningkatkan kreativitasnya. Kreativitas merupakan sebuah kemampuan untuk menciptakan sesuatu yang benar-benar baru atau sebuah kombinasi berupa gagasan ataupun karya nyata. Upaya pengembangan kreativitas merupakan hal penting agar manusia lebih kreatif dan memudahkan individu tersebut bersaing di era modern.

Gaya hidup merupakan sebuah pola perilaku sehari-hari manusia yang dilakukan secara terus menerus dalam kehidupan bermasyarakat. Gaya hidup manusia memiliki dampak yang sangat besar bagi individu tersebut, karena sesuatu yang dilakukan secara berulang-ulang akan membentuk sebuah pola pikir manusia sehingga membentuk karakter dari individu tersebut.

Anton Ismael merupakan pekerja kreatif pada profesinya yaitu fotografer, Anton Ismael yang kerap disapa "Pa'e" ini telah mendirikan sekolah fotografi gratis berbasis komunitas yaitu Kelas Pagi, di samping membuat Kelas Pagi Pa'e juga memiliki perusahaan yang bergerak di bidang kreatif yaitu Third Eye Space. Anton Ismael dikenal dengan seseorang yang memiliki jiwa sosial yang tinggi. Salah satu buktinya adalah mendirikan sekolah fotografi gratis di tiga kota besar yaitu Jakarta, Yogyakarta, dan Papua. Dia selalu membagikan pengalaman-pengalamannya kepada muridnya tidak hanya tentang fotografi tetapi juga pandangan hidup.

Sebagai orang kreatif, Anton Ismael tentu juga manusia biasa yang memiliki gaya hidup yang dilakukan sehari-hari sehingga membuat penulis tertarik meneliti gaya hidup Anton Ismael sehingga menjadikan dia manusia kreatif pada profesi fotografer. Bedasarkan ketertarikan dan latar belakang di atas penulis melakukan penelitian ini dengan berjudul "Gaya Hidup dan Kreativitas (Studi Deskriptif Kualitatif Pada Anton Ismael)". Dalam penelitian ini, ada beberapa teori yang bisa digunakan penulis, antara lain: teori yaitu teori kreativitas, teori gaya hidup, teori profesi, dan teori eksistensi. Teori-teori inilah yang mendukung penulis dalam mempertajam penelitian yang penulis lakukan.

\section{Metode Penelitian}

Berdasarkan Bodan dan Taylor (dalam Moleong, 2012: 3), pendekatan secara kualitatif sebagai prosedur penelitian yang menghasilkan data deskriptif berupa katakata tertulis maupun lisan dari orang atau sumber yang diamati. Jenis penelitian yang penulis gunakan adalah penelitian kualitatif deskriptif. Pada penelitian kualitatif tidak merumitkan perhitungan angka pada statistika sosial namun lebih ditekankan pada data dari hasil observasi dan wawancara peneliti dengan narasumber yang diterjemahkan dalam tulisan baku. Tipe penelitian deskriptif yaitu dengan memaparkan subjek penelitian, tipe penelitian ini didasarkan pada pertanyaan dasar yaitu "bagaimana". Pada penelitian ini metode kualitatif deskriptif memudahkan penulis untuk meneliti bagaimana gaya hidup Anton Ismael membentuk proses kreativitas dirinya.

Studi kasus merupakan strategi penelitian yang penulis pakai dalam penelitian ini. Pandangan Smith dalam Emzir (2010: 20), penelitian studi kasus merupakan salah satu penelitian kualitatif yang memaksimalkan pada penemuan makna, penyelidikan 
proses, dan mendapatkan sebuah pengertian dan pemahaman yang mendalam dari individu, kelompok, atau situasi.

Subjek yang terdapat pada penelitian adalah individu, benda, atau kelompok sebagai sumber data yang dibutuhkan dalam pengumpulan data penelitian. (Idrus 2009: 91). Subjek penelitian ini ialah Anton Ismael. Objek penelitian merupakan masalah atau tema yang diteliti. Objek penelitian merupakan inti penelitian, yaitu apa selaku bidikan penelitian. Objek dalam penelitian ini adalah gaya hidup dan kreativitas.

Ada beberapa metode pengumpulan data yang dapat digunakan penulis agar dapat mengumpulkan data, informasi yang lebih dalam untuk diolah dengan bermacam cara, yaitu sebagai berikut:

1. Wawancara

Wawancara digunakan sebagai teknik pengumpulan data apabila peneliti ingin melakukan studi pendahuluan untuk menemukan permasalahan yang harus diteliti, tetapi juga apabila peneliti ingin mengetahui hal-hal dari responden yang lebih mendalam (Sugiyono, 2011:317).

2. Observasi

Observasi yang dipakai adalah observasi non-partisipan, peneliti tidak terlibat langsung dan hanya sebagai pengamat independen (Basrowi dan Suwandi, 2008: 109).

3. Studi Kepustakaan

Dalam penelitian ini penulis menggunakan metode studi kepustakaan untuk mencari data melalui sumber baik itu dari buku-buku refrensi yang berkaitan dengan penelitian ini (Nazir, 2011:101).

\section{Hasil Temuan dan Diskusi}

\section{Kreativitas}

Karakter kreatif / kreativitas sangat kental dalam diri Anton Ismael. Penulis memilih kreativitas Anton Ismael sebagai bahan penelitian untuk menggambarkan kreativitas orang. Menurut Munandar (2012: 99), kreativitas adalah kemampuan untuk membuat kombinasi-kombinasi baru, asosiasi baru berdasarkan bahan, informasi, data, atau elemen-elemen yang sudah ada sebelumnya menjadi hal-hal yang bermakna dan bermanfaat.

Suratno (2005: 24) memberikan kesimpulan pengertian kreativitas dari beberapa orang yang ahli yaitu bahwa: kreativitas adalah cara perwujudan dari kecerdikan dalam bereksplorasi sesuatu yang bernilai; kreativitas merupakan hasil dari pola pikiran yang mampu dan berdaya.

Anton Ismael sendiri adalah orang kreatif yang selalu bersiasat atau mengandalkan pola pikirnya untuk menjadi kreatif, bukan hanya melulu tentang karya, tetapi juga kreatif dalam menyelesaikan permasalahan-permasalahan yang ada.

"Kreatif itu sebuah tindakan yang sangat sarat akan sebuah siasat, sebuah pola pikir yang sarat akan sebuah siasat.”(Anton)

"Kalau misalkan saya fotografer tetapi saya tidak bisa hidup dari fotografer artinya saya bukan orang kreatif karena saya tidak bisa menyelesaikan permasalahanpermasalahan saya sebagai fotografer. Karena orang kreatif selalu bisa menyelesaikan permasalahan-permasalahan mereka." (Anton) 


\section{Gaya Hidup}

Gaya hidup merupakan sesuatu pola tingkah laku sehari-hari segolongan manusia didalam kehidupan bermasyarakat, termasuk Anton Ismael dimana dia memiliki juga pola tingkah laku sehari-hari didalam masyarakat. Penulis memilih gaya hidup kreatif Anton Ismael sebagai bahan penelitian untuk menggambarkan gaya hidup manusia.

Gaya hidup menurut Setiadi (2008:148) merupakan cara hidup diidentifikasikan oleh bagaimana orang menghabiskan waktu mereka (aktifitas) apa yang mereka anggap penting dalam lingkungannya (ketertarikan), dan apa yang mereka pikirkan tentang diri mereka sendiri dan juga dunia di sekitarnya (pendapat).

Anton Ismael berpendapat bahwa gaya hidup juga berkaitan dengan lingkungan dan menciptakan sebuah pola pikir sehingga kehidupan seseorang terbentuk.

Gaya hidup Anton Ismael yang membantu pembentukan proses kreativitasnya yaitu melihat sesuatu dari segala sisi, berteman dengan semua orang, selalu mengembangkan jaringan, terus belajar, elaborasi diri.

"Saya selalu memiliki konsep bahwa kamu adalah seseorang yang dekat dengan diri kamu, kamu adalah seseorang yang dekat dengan lingkungan kamu. Makanya kamu tahu pameran solo exhibition yang berjudul rumah? Bahwa bagaimana rumah itu membentuk sebuah pola pikir kita, rumah itu bukan dilihat dari bentuk fisik, tapi rumah satu tempat yang bisa non-fisik ya, lingkungan juga bisa."(Anton)

"Kita memotret kenapa? Karena sebuah pola pikir yang menggerakan kita sehingga kita melakukan sebuah kegiatan yang namanya memotret. Pola pikir yang seperti apa? Pola pikir tentang satu hal yang mungkin dipengaruhi oleh masa lalu saya, oleh keluarga saya yang membentuk saya sehingga cara saya berkomunikasi itu lebih cocok ke visual" (Anton)

\section{Profesi}

Sebutan profesi sudah familiar terdengar oleh banyak orang yang merupakan sebuah hal yang berkaitan dengan bidang yang disebabkan oleh pendidikan, keahlian, dan pengalaman, sehingga banyak orang yang bekerja tetap sesuai. Kita tidak hanya mengetahui sebuah profesi untuk bidang-bidang pekerjaan seperti kedokteran, guru, militer, pengacara, dan semacamnya, tetapi meluas sampai mencakup pula bidang seperti manajer, wartawan, pelukis, penyanyi, artis, sekretaris, fotografer dan sebagainya.

Anton Ismael memiliki keahlian fotografi sehingga dari fotografi tersebut membuat Anton memiliki profesi yaitu fotografer.

Sudarwan Danim merujuk pendapat Howard M. Vollmer dan Donald L. Mills berpendapat bahwa profesi adalah suatu pekerjaan yang menuntut kemampuan intelektual khusus yang diperoleh melalui kegiatan belajar dan pelatihan yang bertujuan untuk menguasai keterampilan atau keahilan dalam melayani atau memberikan advis pada orang lain dengan memperoleh upah atau gaji dalam jumlah tertentu. (Danim, $2010: 56$ ).

Anton Ismael memiliki keahlian melukis, menggambar, dan juga mendesign. Tetapi Anton memilih berprofesi sebagai fotografer karena fotografi itu instan dan cepat, dan juga ia dikenal secara professional sebagai fotografer.

"kenapa foto?, mungkin karena itu instan dan cepat. Saya bisa melukis, tapi kaya untuk berkomunikasi saya lebih banyak memotret. Tapi apakah saya melukis? Iya saya melukis juga. Apakah saya mendesign? Iya 
saya mendesign juga. Tapi kebetulan saja orang mengenal saya sebagai seorang fotografer karena saya secara professional profesi saya adalah seorang fotografer." (Anton)

\section{Eksistensi}

Soren Kierkegaard merupakan tokoh ahli dalam eksistensialisme yang pertama kali mencetuskan kata "eksistensi" pertama di abad ke 20an, Kirkegaard berpendapat bahwasannya seluruh realitas eksistensi hanya bisa dialami secara subjek dengan manusia, dan mengasumsikan bahwa kebenaran adalah manusia yang bereksistensi. Menurut pendapat Soren Kirkegaard, eksistensi merupakan sebuah ketentuan yang berani dipegang manusia dalam penentuan arah kehidupnya, dan mendapatkan dampak yang telah diambil manusia.

Tiap eksistensi memiliki cirinya yang khas dan berbeda satu dengan yang lainnya. Kierkegaard telah mengelompokan menjadi beberapa tahap. Salah satunya adalah tahap estetis (the aesthetic stage). (Tjaya, 2004: 89)

Kirkegaard juga berasumsi bahwasannya eksistensi manusia bukan hanya stagnan namun bisa menjadi. Artinya manusia selalu bergerak dari kemungkinan untuk menjadi suatu kenyataan.

Anton Ismael juga merupakan orang yang selalu bereksistensi dalam hal karya foto. Dia selalu membuat foto dengan ciri khas dirinya dengan mengandalkan pola pikir sebagai fokusnya, sehingga setiap orang yang melihat karyanya seperti melihat "diri" Anton Ismael.

"Kreatif dalam fotografi itu banyak hal, tetapi saya tidak.. hmm..., maaf ya, tetapi saya mengesampingkan itu. Jadi yang jadi fokusnya itu adalah pola pikir saya, karena ya pola pikir saya seperti apa ya saya ungkapkan dalam fotografi. Entah orang ini setuju atau tidak setuju tapi saya memberikan sebuah statement dulu gituloh yakan" (Anton)

Nilai estetis juga merupakan nilai yang sangat kental didalam fotografi, karena fotografi merupakan hal yang sarat akan keindahan. Hal ini juga terkandung didalam diri Anton Ismael karena dirinya berprofesi sebagai fotografer dimana pekerjaannya yaitu melakukan fotografi.

\section{Simpulan}

Gaya hidup Anton Ismael membantu pembentukan dan pengembangan proses kreativitas dirinya yang berprofesi sebagai fotografer. Gaya hidup Anton Ismael seperti berteman dengan semua orang, selalu mengembangkan jaringan, terus belajar, elaborasi diri, itulah hal-hal yang sangat mendorong kemampuan kreativitas Anton Ismael sehingga menjadikan dia manusia kreatif seperti sekarang.

\section{Ucapan Terima Kasih}

Terima kasih ditujukan kepada Tuhan Yesus sang pencipta, papa mama dan narasumber yaitu Anton Ismael sebagai subjek penelitian, Bang Moses salah satu petinggi Galeri Foto Jurnalistik Antara (GFJA) sebagai narasumber pendukung. Selain itu terima kasih juga ditujukan kepada Romo Gregorius Genep Sukendro, S.Sos., M.Si., karena telah banyak membimbing penulis ke arah yang benar, serta temanteman yang sudah banyak membantu dalam penyelesaian penelitian ini. 


\section{Daftar Pustaka}

Basrowi dan Suwandi. (2008). Memahami Penelitian Kualitatif. Jakarta: Rineka Cipta Danim, Sudarwan \& Khairil. (2010). Profesi Kependidikan. Bandung: Alfabeta.

Emzir. (2010). Metodologi Penelitian Pendidikan:Kuantitatif dan Kualitatif. Jakarta.Rajawali Pers.

Hidya Tjaya. (2004). Kierkegaard dan Pergulatan Menjadi Diri Sendiri. Jakarta: Gramedia Pustaka Utama

Idrus, M. (2009). Metode penelitian Ilmu Sosial. Yogyakarta: PT. Gelora Akasara Pratama.

Moleong, Lexy J. (2012). Metodologi Penelitian Kualitatif. Bandung. PT Remaja Rosdakarya.

Moh, Nazir. (2011). Metode Penelitian (cetakan ke 6). Bogor: PT. Ghalia Indonesia.

Munandar, S.C. Utami. (2012). Pengembangan Kreativitas Anak Berbakat. Jakarta: Rineka Cipta.

Setiadi, Nugroho J. (2008). Perilaku Konsumen, Konsep dan Implikasi untuk Strategi dan Penelitian Pemasaran. Jakarta: Kencana.

Sugiyono. (2011). Metode penelitian kuantitatif, kualitatif dan R\&D. Bandung: Afabeta.

Suratno. (2005). Pengembangan Kreativitas Anak Usia Dini. Jakarta: Departemen Pendidikan Nasional. 